\title{
Renewing the Pacific Partnership ${ }^{1}$
}

Charles E. Morrison

Presidente del East-West Center, Presidente del Consejo de Cooperación

Económica del Pacífico (PECC).

Peter A. Petri

Senior Fellow del East-West Center; Carl Shapiro, Profesor y ex Decano del Brandeis International Business School.

The rise of China, India, and other Asian nations is creating a new «core» of the world economy centered on the Pacific. It is essential for the United States to remain vigorously engaged in this region, yet the climate of our relations with Asian partners is cooling. The United States and Asia have yet to find a way to cooperate effectively on any significant global issue. This dilemma, we argue, requires urgent attention on both sides of the Pacific, and specifically a U.S. strategy that features innovative civil diplomacy alongside official initiatives.

\section{The Challenge}

Asia already accounts for about half of the world's people and nearly a quarter of its output and financial assets (figures

\footnotetext{
1 Publicado en East-West Dialogue, $\mathrm{N}^{\circ} 1$, septiembre de 2007. Reproducido con la debida autorización del East-West Center, Honolulu.

2 We use the term Asia to refer to Asian countries that vigorously participate in the global economy, including most countries in Northeast and Southeast Asia and India.
} 
1 and 2). Over the past forty years, all of the world's fastest growing economies (those with per capita income growth of 5 percent or more) were Asian, and China, India, and Vietnam are topping global growth charts today. This unprecedented «Asian miracle» has lifted hundreds of millions of people from poverty to middle- and even upper-income lifestyles.
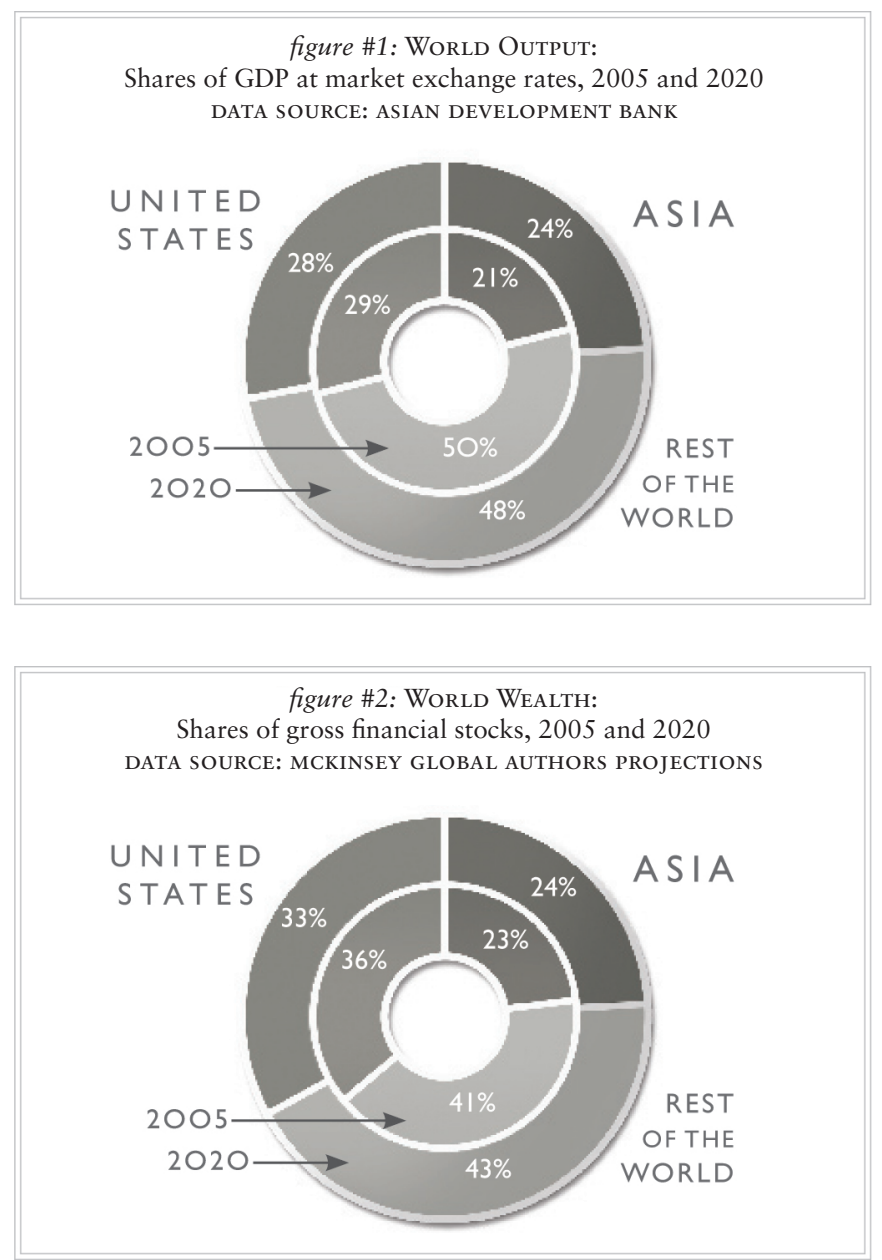

And the miracle continues. The region has recovered forcefully from the financial crisis of 1997-98, and its future progress is ensured by investments in physical assets and education (figures 3 and 4) that already exceed those of the United States. Asia's share of world output doubled in the last 50 
years and will probably double again in the next 50 . We need to prepare for a world in which Asia will overtake the United States in many important aggregate economic measures.
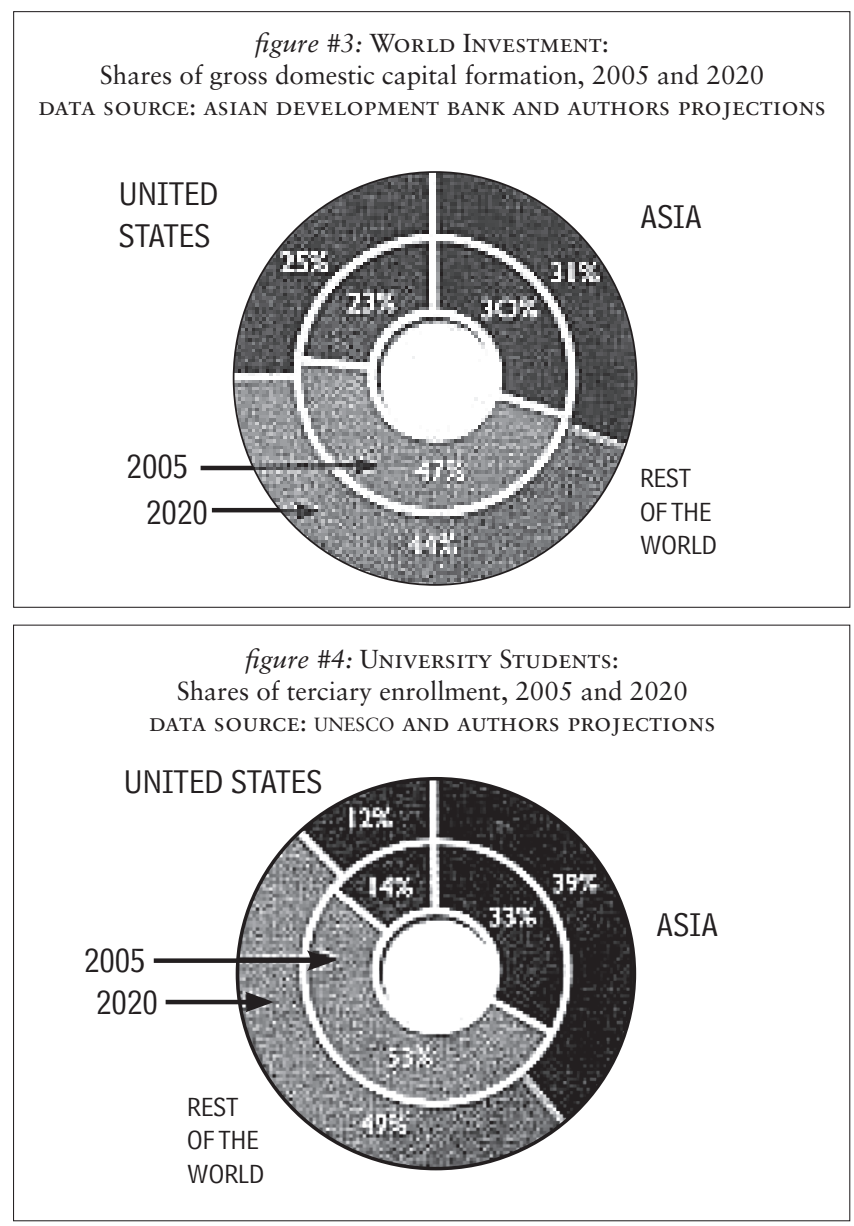

Given these remarkable trends, the United States and Asia share a vital stake in Asia's peaceful rise. It is essential that Asia's major powers and the United States become, in the words of World Bank President Robert Zoellick, «responsible stakeholders» in a stable, prosperous world order. The United States still has great influence in shaping this order, but time is limited. We need to make sure that strong, cooperative institutions emerge, and that the United States itself is firmly established as an attractive model and trusted partner for Asia. 
Yet for now, the chemistry of the Asia-U.S. relationship is failing. While recent relations among governments have been positive, public attitudes have soured. This may be due to the anxieties of economic competition, which find voice in sensationalist press reports and the politicization of complex trade and currency issues. The results are harmful: a recent BBC poll found that America's «influence in the world» is viewed positively by only 28 percent of Chinese and 37 percent of other Asians, while China's influence is viewed positively by only 34 percent of Americans and 43 percent of other Asians. And the positive opinions are decreasing.

The public climate is cooling despite the fact that the United States currently enjoys its best official relations ever with China, Japan, and India. It engages these countries at many levels including the top leadership. Asian countries, in turn, have been pragmatic and collaborative in their relations with the United States - by being more willing than Europeans, for example, to set aside their reservations about U.S. Middle East policies in direct relationships.

\section{Renewing the American Partnership with Asia}

What is lacking is a coherent vision for the trans-Pacific relationship, built on an equal partnership of the United States and major Asian countries, and implemented through mutually valued collaborative initiatives. This cannot be accomplished through bilateral relationships, or through regional institution building in Asia. A strong trans-Pacific framework, we believe, would strengthen not only U.S. connections with Asia but also the Asian region's ability to cooperate internally.

The United States has been and remains a key driver of economic growth in Asia. This is due in part to policies that reduced barriers to economic interaction, and in very large part to a myriad of business and personal decisions on investments in and imports from Asia. U.S. military assets and alliances in the region have been also widely regarded as stabilizing.

The post-Cold-War efforts of the United States to refashion its relations with Asia Pacific countries crystallized in 1989 in its participation in launching the Asia Pacific Economic 
Cooperation (APEC) forum. President Clinton later helped to elevate APEC to the leaders' level, and the forum then seemed destined to become a principal element of a new global architecture. But APEC's effectiveness weakened with the over-expansion of its membership and disappointments in its economic results - both in trade liberalization and in handling the Asian financial crisis. Nevertheless, APEC remains the most logical vehicle for regionwide cooperation. As we argue below, it should remain central to America's strategy for the Asia Pacific partnership.

\section{FAlse Choices}

Since the financial crisis, Asian countries have shown renewed interest in narrower regional institutions of economic cooperation. Alternatives include ASEAN+3 (which China supports, since it is likely to play a leading role in it), and ASEAN+6 (which Japan supports, expecting Australia, New Zealand, and India to dilute China's influence). The United States has not opposed these groupings, as it had the East Asia Economic Group in the early 1990s, but APEC remains its preferred regional economic architecture.

These arrangements are often viewed as stark alternatives in competition with each other. But the view that integration has to be either Asian-only or Pacific-wide presents a false choice. Each has advantages. They can be maximized when both are pursued in parallel.

Intra-Asian integration is desirable because it can facilitate the region's rapidly deepening economic connections. Asian integration has been accelerated also by the political repercussions of the Asian financial crisis. The crisis demonstrated the region's financial interdependence and highlighted the absence of an adequate regional framework for handling regional emergencies.

Trans-Pacific ties are at least as important. Asian trade, while reflecting extensive intra-Asian exchanges in production, is still largely targeted on final demand outside the region, especially in the United States. U.S. capital markets help to intermediate Asian savings, and U.S. firms invest heavily and 
productively in Asia. The United States also remains an essential source of technology and of assets attractive to Asian investors. The same relationships, viewed in reverse, show how interdependence benefits the United States.

The United States cannot expect Asia to choose between regional integration and Pacific integration, much as it would refuse to choose between the North American Free Trade Agreement (NAFTA) and relations with Asia. On their side, Asians cannot neglect their commercial and political stakes in North America. In today's global economy, regional integration is best understood as a means for strengthening a region's global competitiveness: it is a complement to, and not a substitute for, broader partnerships.

\section{Improving the Chemistry of Asia-U.S. Relations}

We would prefer to see parallel regional and trans-Pacific trade agreements and a successful conclusion to the Doha Round. We would also like to see the U.S. government play a prominent role in rebuilding the Asian partnership. But we recognize that these outcomes are not in the political cards for now. In fact, the U.S. government may have its hands full just defending and building its relations with China and securing approval of the free trade agreement with South Korea. So what can be done?

First, strategic planning. There is important, quiet work to be done by governments in building a vision for an Asia-U.S. policy, to be implemented as political opportunities permit. Some key elements are already in place. On the political side, these include the U.S. alliance system, the Senior Policy Dialogue with China, and the Six Party Talks. In economics, there are APEC and the Strategic Economic Dialogue with China. But these institutions have been created ad hoc; they cover neither the region as a whole, nor all critical issues. A thoughtful framework is needed, identifying all important interactions and channels for addressing them. The channels do not have to be formal, but they should involve senior officials and, as appropriate, people outside government, and should have adequate resource and analytical support. 
Second, regional institutions. Since APEC is the centerpiece of the American multilateral relationship with the region, the United States needs to give it greater and more consistent emphasis. APEC's proposal for a Free Trade Area of the Asia Pacific, however compelling it may be in the long run, is not likely to gain traction for a variety of reasons, including the fact that Congress has failed to renew the President's trade-negotiating authority. APEC needs realistic goals leading to successes. Its mission should be sharpened to cooperation on significant, shared policy interests on both sides of the Pacific. For example, APEC could do valuable work in areas such as health and safety, trade facilitation, energy conservation, financial integration, and educational and cultural exchange. But its products must be well defined, substantial, and recognized as important. APEC should never again allow a major regional economic issue, like the Asian financial crisis, to occur without vigorously addressing it.

To make APEC more effective, the United States needs to upgrade its investment in it and engage broad segments of society in the forum's efforts. In addition to APEC, the Asian Development Bank, with a Pacific-wide membership, substantial resources, and a mission that targets knowledgebased work and regional integration, should also get more attention in Washington.

Third, public diplomacy. Given the constraints on government action, public diplomacy should assume a large role in sustaining the Pacific Partnership. We could usefully borrow a page from China's playbook and launch a U.S. «charm offensive» in Asia. The emphasis should be on civil institutions America's highly regarded business, cultural, and educational assets. This will require some seed funding from government. The United States has gained handsomely from such efforts in the past-for example, leaders around the world have been familiarized with U.S. perspectives through the Fulbright program- yet it has consistently underfunded them. This is no time to be shortsighted, given Asia's trajectory and the potential costs of a breakdown in the relationship. Further, good programs will be inevitably leveraged by the private sector, provided that they are free of public interference.

These steps will not be easy to implement, nor will they quickly eliminate tensions. But the vision of a world economy 
led by Asia and the United States as collegial partners makes the effort enormously worthwhile. This new publication — the East-West Dialogue - is a contribution to that effort. Our goal in this and future issues is to generate a lively exchange on Asia-U.S. issues and, in the process, help build bridges across the Pacific.

\section{The OTher Deficit}

The United States has one of the lowest ratios of «outward student mobility» $(0.2 \%)$ in the world. In 2005, approximately 590,000 foreign students enrolled in higher education in the United States, but only 190,000 Americans were studying abroad. Flows are also sharply imbalanced by region. For each American student in Asia, 20 Asians come to the United States. Most Americans go to Europe. There are good reasons for imbalances -the strength of American universities and the rich cultural assets of Europe quickly come to mind- but increased American exposure to Asian countries would be an obvious plus for civil diplomacy.

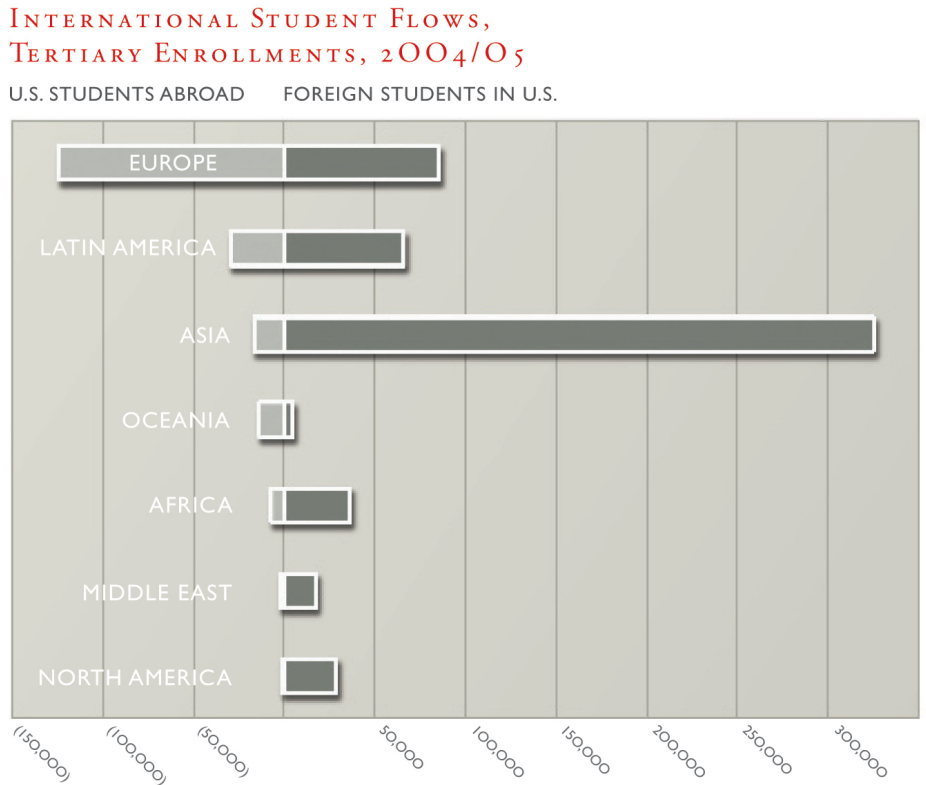

SOURCE: INSTITUTE OF INTERNATIONAL EDUCATION 


\section{COMMENTARIES}

\section{APEC's Moment of Opportunity}

Taeho Bark, Presidente de la Korea International Trade Commission; Decano, Escuela de Postgrado, Universidad Nacional de Seúl.

East Asian countries began to enter into regional trade agreements (RTAs) relatively late. Although they have been expanding such agreements since the late 1990s, their shift toward regionalism has failed thus far to catch the attention of the world economic community. Most intraregional agreements have been "shallow» in scope and depth, whereas more of the trade agreements concluded by the outward-looking East Asian countries have been interregional.

Since Korea completed its negotiations for a free trade agreement (FTA) with the United States and started negotiations with the European Union, both China and Japan have shown a great deal of interest in starting FTA negotiations with South Korea. In South Korea, some advocate a Northeast Asian FTA, with all three countries participating. After China, Japan, and South Korea concluded their respective bilateral FTAs with ASEAN (Association of Southeast Asian Nations), some are even suggesting an ASEAN+3 FTA (including Japan, South Korea, and China).

Several factors make an East Asian RTA unlikely: ASEAN countries are at different stages of economic development. South Korea, China, and Japan are still divided by sensitive historic, political, and economic issues. China and Japan are still wary of each other in the competition for leadership within East Asia. Finally, for East Asian countries, interregional trade is still more important than intraregional trade, and therefore the need for an East Asian RTA is not felt very acutely.

For the time being, the dialogue will be pursued along two separate tracks simultaneously -the negotiations for inter-and intraregional trade agreements, alongside the talks about an agreement among South Korea, China, and Japan. If the latter is not aimed at the formation of a single common market but is seen to be an opportunity to move forward with dialogue 
and cooperation, negotiations could start soon. Under these circumstances, the paper by Morrison and Petri, with its call for strengthening Asia Pacific economic ties, is timely.

I agree with the authors' emphasis on APEC. APEC has established a vision in which the advanced member countries will liberalize trade and investment by 2010 and the developing countries will do so by 2020 . The current consensus, however, is that this vision will not materialize. The reason is that APEC's initiatives have, by and large, failed. If the dream of Asia Pacific economic integration through APEC is to be achieved, the credibility of APEC has to be restored. The aim of Asia Pacific economic integration has to be reaffirmed, and the Busan Roadmap produced by the 2005 meeting has to be revisited.

The public diplomacy mentioned by the authors can be achieved in part through different bodies within APEC. The APEC Business Advisory Council (ABAC) can reflect business interests, while the APEC Study Center can provide academic input. Other organizations, such as the Pacific Economic Cooperation Council (PECC) and Pacific Basin Economic Cooperation (PBEC), need to be further activated, with the United States taking on a bigger role.

There are many obstacles along the road to economic integration, but the outlook is much brighter today than it was at the first APEC Economic Leaders' Meeting in 1993. Since then, many reciprocal FTAs have been concluded or are being negotiated within APEC. Many members believe that an APEC-wide FTA has to be considered, just to avoid the entanglements of a «spaghetti noodle» result. If more flexible terms are offered to developing countries, an APEC FTA is not necessarily impossible. It would be beneficial not only to the United States but also to East Asia. Now is the time for the leaders of the APEC member countries to realize the importance of APEC.

\section{Renewing or Reinventing the Pacific Partnership?}

Peter Drysdale, Profesor Emérito y Director del Departamento de Investigación Económica para Asia oriental, ex Director Ejecutivo del Australia-Japan Research Centre. 
Renewal of America's partnership with Asia was never more important than it is today. But the scale and structure of the changes that are taking place in Asia require more than trying to restore an old order, however well it served American and global interests over the past six decades. Arguably reinvention not renewal of America's relations with Asia alone will suffice.

The changes that call for a radically new approach are depicted to some extent in the figures that accompany Morrison and Petri's essay. But those figures are a modest statement of the size of what is going on. It may be reassuring to measure the changing weight of the Asian economy in 2020 at current exchange rates. That hardly makes much sense, however, if you know that the adjustment to China's massive growth will force significant appreciation of the Chinese exchange rate, not now but certainly and inexorably over the next 10 or 15 years. The true size of the Asian economy in 2020 can be more closely approximated by measuring in purchasing power parity rather than the current exchange rate. Currency appreciation alone, even at its present rate, will nearly double the value of Chinese output over this period. By 2020 East Asia's economy will likely be bigger than North America's, conservatively accounting for 36 percent of world output compared with an American share just under 20 percent.

China's economic rise and integral role in the continuing rise of Asia are just part of the sweeping changes taking place in America's relations with Asia. The impact on politics, security, the environment, and every dimension of America's international affairs is structural and fundamental, not just incremental. This is a phenomenon without precedent in America's experience and history as "a rising power.» If it is to be managed with any degree of success, it will require entirely new ways of thinking, most especially in America, about America's and Asia's places in the world.

There are powerful political as well as economic reasons why the institutionalization of regional arrangements in East Asia will be so important in the years immediately ahead. The intensity of intraregional economic relations that is projected in East Asia cannot be secured without a confident political framework. The strategic context in which the region now 
has to shape its political relations with the world has changed dramatically since the end of the Cold War.

The Cold War period was characterized by a stable alliance framework. But that system no longer exists, and no similarly stable system has yet replaced it. In the post-Cold War period, friends and enemies are not clearly identifiable. Strategic and economic interests compete for attention. And the rise of new economic powers such as China is not automatically accommodated within established security structures. Attention to what America needs to do about this is at best diverted by other issues or is at worst in disarray.

There are three broad options that can be now contemplated for the political and security system of East Asia and the Pacific: hegemonic power and order; the reemergence of a power balance; or the construction of a new concord of powers in East Asian and Pacific affairs. However much some might hanker after it, hegemonic power is in retreat. Moreover, any system that relies on power balance alone in the East Asian and Pacific theater is likely to see Japan and the rest of East Asia straddling their two most important relationships in the region - the relationship with China and the relationship with the United States - in some critical circumstance at great cost to themselves and to the region. The strategic focus must clearly be on constructing an effective and durable concord of powers in the region.

The East Asian economic cooperation structures already in place are the first crucial, if tentative, steps in building a durable concord among powers in the region. If adequately reinforced, East Asian economic arrangements can be effective in mollifying the political tensions and security concerns emerging from the rise of China over the years ahead.

Based on solid economic and political arrangements within East Asia, a broader concord can then be built to secure the constructive engagement of America. The challenge for both East Asia and America, then, is to develop a strategy that embeds the structures of East Asian cooperation within transregional cooperation arrangements such as APEC, as Morrison and Petri suggest.

No one in America or Asia has yet put the effort into defining a strategy to serve this purpose. The concept that 
must be developed is a regional architecture for Asia and the Pacific, organized around both the established and the rising powers.

It is more than timely to invite the East-West Dialogue to continue to define cooperative ways forward and a strategy that will serve both America's and Asia's interests better than any that are presently in contemplation.

\section{Building a Mutually Indispensable U.S.-Asia Bond}

Shen Dingli, Director del Centro de Estudios de América, Decano Ejecutivo del Instituto de Asuntos Internacionales, Universidad de Fudan, República Popular China.

The present-day quest for productivity and profit, especially through manufacturing, has led players around the globe to find efficient ways to trade their strengths. China and India are seeking capital, technology, and markets in the West. The West in turn is outsourcing some of its labor needs, to take advantage of low costs in Asia. In the globalizing economy, both America and major Asian countries are relying on mutually beneficial pragmatism rather than potentially divisive ideology.

This growing economic interdependence is not only beneficial to all parties but also strengthens the chances of peace in the Asia Pacific region. At the same time, the center of economic gravity is shifting from the Atlantic to the Pacific, and especially to East Asia. Projections show that China has a strong chance to overtake America in the next two decades in terms of economic output. Projections using purchasing power parity give an even earlier date. India may have a similar but more distant chance by mid-century. Obviously, these challenges, together with many questions about how to cope with them, give American policymakers a lot to ponder.

The inaugural essay of the East-West Dialogue by Charles E. Morrison and Peter A. Petri addresses the U.S. response to the rise of China, India, and other Asian economies and observes that America must be firmly established as an attractive model and trusted partner for Asia. The authors 
propose a threefold approach for the United States to renew its partnership with Asia: strategic planning, regional institutions, and public diplomacy. In their view, these elements can be woven into a new fabric of peaceful, joint leadership for the world economy.

Above all is the vision that the United States must stay in Asia and interact constructively with its Asian partners. Intra-Asian ties have to be strengthened, and there is a need for action to promote U.S.-Asian multilateral collaboration. We do not have to look far to find reasons why progress has been slow. Factors that immediately come to mind are Asia's political and cultural diversity, and the polarization lingering from historical conflicts, in part still reflected by America's current alliances in the region.

Morrison and Petri argue for a revitalization of the U.S. partnership with Asia through the two-pronged approach. They argue for supporting regional integration, and also cooperation within a trans-Pacific context, in which America participates more directly. From the viewpoint of strategic planning, now that the Six Party Talks have achieved their initial objective and plutonium facilities of the Democratic People's Republic of Korea (North Korea) are shutting down, the time is gradually becoming right to develop a genuine security dialogue and confidence-building mechanism among the nations of Northeast Asia.

At the same time, the United States has a unique opportunity to engage Beijing, Tokyo, and New Delhi constructively. As the authors point out, U.S. ties with China, Japan, and India are now at a historical high point. The United States would benefit most by shifting away from the old concept of checks and balances and, instead, helping to forge a regional partnership among the three large Asian powers and taking a leadership role in this process. The effort to achieve a more balanced relationship among them and to nurture mutual accommodations needs America's active participation and will help to keep the United States firmly engaged in the region.

Morrison and Petri have defined APEC as the centerpiece of America's multilateral relationship with Asia, and APEC does indeed need «realistic goals leading to successes.» It will not be difficult to identify problems for APEC to work on, 
but these problems must be of mutual interest to both sides of the Pacific. During the next 10 years, America's output and share of world wealth will still be ahead of Asia's, giving the United States sizable leverage to initiate multilateral negotiations that will deliver tangible outcomes. As long as America can help to generate public goods for Asia in a timely way, leadership from Washington will remain appealing to America's partners in Asia. 